\title{
Divine Interference in Royal Affairs: New Perspectives on Lu- cina, the Roman Goddess of Birth and Shadow of the Virgin Mary in Catholic Early Modern Spain \\ Interferencias divinas en asuntos reales: nuevas perspectivas sobre Lucina, la diosa romana de los partos y sombra de la Virgen María en la España católica de la Temprana Modernidad
}

\section{Hannah Fischer-Monzón}

Universität Wien

AUSTRIA

hannah.fischer-monzon@univie.ac.at

[Hipogrifo, (issn: 2328-1308), 6.1, 2018, pp. 451-465]

Recibido: 15-01-2018 / Aceptado: 05-03-2018

DOl: http://dx.doi.org/10.13035/H.2018.06.01.32

Abstract. Life is God-given and to give birth begs for divine help. This article seeks to present new perspectives on selected appearances and apparitions of Lucina, the Roman goddess of birth, with respect to birth in the Golden Age of Spain. Ovid, antique's best-known author, paints Lucina as an ambiguous sorceress, volatilely answering prayers. Still, allegoric representations of Lucina relating to the Spanish rulers and high society are found in Spanish literature, art, architecture and medical tractates. The pagan gods are revived in Renaissance art and do not fit into Christian moral codes nor qualify as praiseworthy saints, but nevertheless maintain 
a prevailing source of allegories and figurative images. Lucina's appearances in Francisco Núñez's obstetrical tractate Libro intitulado del parto humano, Pedro Ruiz de Camargo's painting in the Arch of Santa María of Burgos and in Micheli Parrasio's canvas Alegoría del nacimiento del infante don Fernando are described and interpreted. The goddess of birth appears with aspects of Juno, Venus and the Virgin Mary and is blamed when misfortune strikes.

Keywords. Lucina; Juno Lucina; Francisco Núñez; Parrasio; Alegoría del nacimiento; Virgin; Birth; Goddess of birth

Resumen. Las que alumbran piden ayuda divina: en la antigüedad, son las diosas del parto que asisten a las mujeres parturientas. En el Siglo de Oro los dioses paganos ya no son adorados: ellos no caben en los códices morales cristianos, y no califican como santos dignos de veneración, sin embargo, son ellos que sirven como fuente principal de alegorías e imágenes figurativas en la corte y la alta sociedad. La diosa romana de los partos es Lucina, epíteto de Juno. Ovidio la introduce como ambigua hechicera, caprichosa y respondiendo a los rezos humanos según se le antoje. No obstante, ella surge en el Siglo de Oro en el teatro, la poesía, en las artes, y también en tratados obstétricos. Este artículo presenta e interpreta las apariciones de Lucina en el Libro intitulado del parto humano del médico Francisco Núñez, en la pintura de Pedro Ruiz de Camargo en el arco de Santa María de Burgos y en el lienzo Alegoría del nacimiento de don Fernando del pintor Micheli Parrasio. La mitología encubre y poetiza una dura realidad social en la que todo parto ponía en peligro tanto la vida de la madre como la del niño. Lucina aparece con aspectos de Juno, Venus, y la Virgen María, y se le culpabiliza cuando la desgracia golpea.

Palabras clave. Lucina; Juno Lucina; Francisco Núñez; Parrasio; Alegoría del nacimiento; Virgen María; nacimiento; diosa del parto.

Alcmena remembers:

Today I feel once more the pangs of labour.

Seven days, seven nights, I suffered sick and weary.

Raised arms to heaven, crying for Lucina,

With her two goddess-midwives to come to help me.

And she did come'.

And Lucina keeps coming. Birth marks the beginning of life2 ${ }^{2}$. It is both natural and private, but in certain matters a public interest: namely when queens deliver.

1. Ovid, Metamorphoses, Liber 9, 290-295: nec iam tolerare labores ulterius poteram; quin nunc quoque frigidus artus, dum loquor, horror habet, parsque est meminisse doloris. septem ego per noctes, totidem cruciata diebus, fessa malis tendensque ad caelum bracchia magno Lucinam Nixusque pares clamore vocabam. Illa quidem venit [...].

2. This article contributes to the research project El Calderón cómico funded by the FWF Austrian Science Fund, project number P 29115, directed by Wolfram Aichinger, to whom I render my gratitude for his 
The fate of the empire stands and falls with the continuity of its reigning dynasty ${ }^{3}$. However, the inexorable desire to preserve the royal succession had to be paid at a high price; Casa Austria's queens' and infant mortality rates are self-explanatory ${ }^{4}$. Between life and death is an abysmal path. Labours are relentless, life (lives) are at stake and the angel of death is looming ${ }^{5}$. When humans are exposed to their limits, they cry out for divine help: gods are breaching in ${ }^{6}$.

In the Golden Age of Spain, ruled by catholic kings and queens, the pagan realm of demons and gods is still the artists' prevailing source of figurative images and allegories ${ }^{7}$. It might well be that biblical and Judeo-Christian tales were less known or just not profane and frivolous enough to depict the shady sides of life. Should the perfect Virgin Mary simply not suffice as a role model of childbirth, or worse, the misfortune thereof, for reasons of sanctity and respect for the god-bearing Mother of God there is another divine Lady in the "birthing-business": Lucina. She is the one residing left above on the painter Micheli Parrasio's Alegoría del nacimiento del infante don Fernando. She appears in doctor Francisco Núñez' vision in his Libro intitulado del parto humano, and blesses the passers-by in the Arch of Santa María in Burgos. Both, Parrasio and Núñez, each in their métier egregious, are undervalued. Their works are zeitgeisty testimonies of Spanish Golden Age which have not yet reached the limit of potential scrutiny, inviting further investigation. This article therefore endeavours to delve into the realm of this goddess of birth -Lucina- presenting selected appearances and apparitions.

The antique go-to person for women's issues is Eileithyia of Greek descendance, in her ancient roman appearance as Lucina or Juno Lucina, as an independent goddess or merged with attributes and characteristics of Juno or Diana and also Luna ${ }^{8}$. Lucina was worshipped on the Esquiline (Mount Cispius) in Rome, her temple erected in 375 before Christ, where birth statistics were collected. She was celebrated by Roman women and mothers on 1 March at the feast of Matronalia, celebrating

support and counsel.

3. The queen's purposeful function is procreation at its maximum, as Early Modernity Moralists and theoreticians and Spanish Medieval legislations determinated, see García Barranco, 2007, p. 227.

4. Tu felix Austria nube makes the Habsburgs the mightiest ruling dynasty in Europe, but causes also their genetic degeneration and even extinction in certain family branches.

5. Of 34 infants born between 1527 and 1661, ten died before their first birthday. See Bennassar, 1983, p. 23, Margarita García Barranco shows in her statistics, that the number of total gestations was even superior to actual births. See García Barranco, 2007, p. 229.

6. Wolfram Aichinger points to the fact, that there might have been a connection between rising religiosity in Spanish Golden Age's society and risks and danger of pregnancy, see Aichinger, 2014, p. 21.

7. Despite the warnings of the Council of Trent, mythology continues with «renewed ardor» in arts, being justified by its proclaiming of philosophical truths and moral concepts, see Seznec 1995 [1940], p. 269 and p. 278.

8. See Gottschalk, 1993, p. 157 
fertility and the awakening of nature ${ }^{9}$. Her name may derive from the Latin word lux (light) or lucus (grove) ${ }^{10}$.

Most certainly the old gods had no longer received worship and offerings in the medieval epoch and their shrines, if any had been there, lay abandoned in ruins. Albeit, Jean Seznec is of the opinion the Middle Age and Renaissance period to be a continuum of the intermingling and mutual exchangeability of Christian culture and Ancient Belief systems. Still, it was merely their content that survived:

Above all, it is now recognized that pagan antiquity, far from experiencing a "rebirth" in fifteenth-century Italy, had remained alive within the culture and art of the Middle Ages. Even the gods were not restored to life, for they had never disappeared from the memory of imagination of man $^{11}$.

In Spain in the late 16th century the educated members of society were well acquainted with the ancient Greco-Roman pantheon, or at least with its most prominent figures as they appear in the books of Homer, Vergil and Ovid ${ }^{12}$. Little information can be obtained thereof. Homer introduces a daughter of Zeus and Hera in charge of the labours of birth ${ }^{13}$. Ovid, in his roman calendar, counsels the women in labour on how to pray to Lucina ${ }^{14}$.

The best-known text that features Lucina is the tale of Alcmena birthing Hercules in Ovid's Metamorphoses. In this story, Lucina is involved in a plot to avoid, respectively delaying, the birth of Jupiter's lovechild. She, not quite godly, shows a higher loyalty to Juno, the ever jealous and cheated-on spouse who won't suffer Alcmena having their son Hercules born. Lucina does not at all support the labouring mother-to-be and when finally, the birth against all odds goes well, the untrustworthy goddess of birth takes revenge on the midwife and transforms her into a weasel ${ }^{15}$. Lucina's qualities as a trustworthy helper in birth are found in the tale of Adonis' birth, paralleling the incestuous pedigree of ruling houses: Myrrha, impregnated by

9. See Backe-Dahmen, 2008, p. 19. Juno is also connected to the feast of Lupercalia, celebrated on 15 February, which included fertility rituals, in this context, an analysis of Andrea Camassei's Fiestas Lupercales 1635, exhibited in Museo del Prado, Madrid, is suggested.

10. See Radke, 1965, p. 188. Cicero prefers the 'light' version in contrast to Pliny. Lux as the etymological origin seems more plausible, since birth refers to being brought into light or to having one's eyes opened as evident in the Spanish lexicon in reference to birth, such as alumbrar, alumbramiento, dar a luz, whereas the mere fact of her shrine standing in a grove does not sound, as the source of a name, too convincing. After all, not every grove-dweller's name is grover, nevertheless, grove might also be associated with fertility.

11. Seznec, 1995 [1940], p. 3.

12. Intermediaries, contemporary manuals and dictionaries were also important sources such as Giovanni Boccaccio's Genealogia deorum gentilium (1350-1367), and Juan Pérez de Moya's Philosophia secreta, published 1585 in Madrid in Spanish language, see Seznec, 1995 [1940], pp. 317-318. Italy and all of Europe were inundated by moralized editions of Metamorphoses, see Seznec, 1995 [1940], p. 226.

13. Homer, Ilia 11, 270.

14. Ovid, Fasti 2, 2 and Fasti 3, 257.

15. Ovid, Metamorphoses 9, 273-330 
her own father, thus hexed into a tree, cries out in painful labour. Lucina, pitifully lays hands on the groaning tree, pronounces relieving words and Adonis is born ${ }^{16}$.

As also stated by Petersmann, the simple Romans worshipped Lucina as an epitheton of Juno, meaning they were identical, though Lucina's origin(s) as an independent goddess are found in the ancient Sabin tradition. Petersmann deduces Juno's split in two separate and individual goddesses to the poet's virtuosity in his Metamorphoses by interweaving various mythological traditions ${ }^{17}$. Juno's tasks of birth and labour are personified in Lucina, who steps into Eileithyia's, the Greeks' goddess of birth's responsibilities.

Mythological figures and motives are quite commonly used but each artist takes the liberty to transform them according to his intention, using them allegorically, adding to, or detracting from, their few yet plain character traits. Ancient gods don't come in glory and power. They are flawed and errant and their personalities become synonymous with their prevailing failure or their assigned duty thus well-serving as totum pro parte. Ovid's virtuosity and creativity may have been the artist's most inspiring source, though as Martínez Berbel states, each author converts Ovid into a personal one:

El resultado de todo este complejo proceso es una nueva mitología, cuyas fuentes inmediatas ni siquiera son las originales, sino a menudo, diccionarios, traducciones, mitografías que, como en el caso de Lope, esconden sutilmente el Ovidio original (en este caso) sustituyéndolo en un Ovidio renacentista al que, posteriormente, cada autor convertirá en un Ovidio personal ${ }^{18}$.

\section{LUCINA APPEARS IN THE DOCTOR'S VISION}

In the year 1580 doctor Francisco Núñez de Coria's medical treatise Libro intitulado del parto humano was published. The Toledian, who studied and taught at the university of Alcalá, appeals to not only doctors and midwives, but also to pregnant and childbearing women, their husbands and anybody who might be interested in child birth. Its purpose is to «reduce pain and risks of labour and to turn difficult births into easy ones» ${ }^{19}$. His treatise might well have certain recognition in medical science but still holds concealed culturally-historic pearls yet to be exposed ${ }^{20}$. The book is dedicated to Isabel de Avellaneda and her husband don ínigo de Carde-

\footnotetext{
16. Ovid, Metamorphoses 10, 501-520.

17. Petersmann, 1990, p. 158.

18. Martínez Berbel, 2003, p. 32. Fernando de Herrera describes Lucina in his Anotaciones a Garcilaso as a fusion of Juno, Lucina, Diana and Lucretia, see Herrera, Obras de Garcilaso de la Vega con anotaciones, p. 497, Pérez de Moya explains, that Juno is called Lucina, when referring to the goddess Luna, see Pérez de Moya, Philosophia secreta, p. 409.

19. Núñez, Libro intitulado del parto humano, fol. 16v. translated by H. F.

20. A critical edition does not yet exist.
} 
nas $^{21}$ - parents of eleven children, a powerful couple ${ }^{22}$, members of high society and close to the king. Content and style refer to Greco-Roman medical heritage and authorities ${ }^{23}$. Núñez distinguishes himself not only as a doctor, but as a poet by including poems, and even as a poeta vates, invocating divine help. In his prologue he stages a vision: tired and weary of work he falls asleep under some trees and suddenly finds himself sailing the sea -a symbol of the amniotic fluids and the fountain of life ${ }^{24}$ - when all of a sudden strong winds and high waves rise and float him ashore. Grasping the pending branches of dense trees he escapes the ranging sea. Stung by pricks and thorns he reaches a grove. He manages to escape the frightening and dangerous golf and finally reaches a locus amoenus a heavenly and peaceful place in divine harmony amidst singing birds and sweet flagrances when he suddenly sees an «agradecida nimfa» ${ }^{25}$ approaching him. The doctor has her appearing as breathtakingly beautiful, her head adorned with a wreath of colourful flowers and dressed in a blue, gem-stoned robe ${ }^{26}$ with a golden vessel of honey overflowing in her left hand and branches in her right 27 , with white milk flowing out of her marbled breasts. She introduces herself as the goddess of birth and tells him not to be afraid: «No temas, porque te hago saber que me llamo Lucina, y por otro nombre la diosa de los partos» ${ }^{28}$. She then interprets his dream: she tells him the spiky trees are his adversaries with the ocean being the world in disarray. She praises Isabel and don Îñigo, whom she gifted with an «ilustre generación», their scores of children, to be of her, the goddess herself29. The goddess as a procurer of a plentiful progeny has a predecessor in roman imperial numismatic: Her coinage on the backside of a Roman coin, where she is portrayed with an infant on her left arm and two older children as an embodiment of fertility ${ }^{30}$.

Compared to other occurrences of the goddess, Francisco Núñez's Lucina appears without any mythological context and references: there is no Alcmena, no peacock, no crescent moon but a Lucina as an autonomous, independent goddess and authority in abundance of attributes, character and functions. He refers to the

21. Núñez, Libro intitulado del parto humano, fol. 4r.

22. Don Íñigo de Cardenas was the president of the royal council, his wife was the sister of the marine Capitan Bernardino de Avellaneda, who served three kings, Philip II, III and IV. See Martínez Hernández, 2004, p. 183 and Campus Hernán/Moreno Martín, 2005.

23. He is Hippocrates' and Galen's disciple and applies their theories of humourism.

24. See Forstner, 1967 [1961], p. 73.

25. Núñez, Libro intitulado del parto humano, folio 11r. The vision is described on fols. 10-13.

26. The gem-stoned blue rope might be an allusion to the starspangled cloak.

27. He even gives the plant's names, Aristolochia Clematitis, which resembles female genitals and Anagyris foetida, not surprising, with pods in the shape of phalli. See Núñez, Libro intitulado del parto humano, fol. $11 \mathrm{r}$.

28. Núñez, Libro intitulado del parto humano, fol. 12v.

29. Núñez, Libro intitulado del parto humano, fol. $13 \mathrm{r}$.

30. The coin pictures on the front side Faustina Minor, Marc Aurel's wife, mother of thirteen children, who stands for imperial fertility (fecunditas Augustae) in order to promote and guarantee the dynastic continuity (aeternitas imperii), see Backe-Dahmen, 2008, p. 19. 
offerings on her head and the branches in her hand ${ }^{31}$ : milk and honey ${ }^{32}$ in the midst of a fertile and blooming landscape. The doctor, evidently well versed in classic perceptions of the pantheon, sets the deity on purpose. Núñez invigorates the goddess of births designating her as his advocate speaking on his behalf with a certain intent. Far from being allegoric, she becomes the main character of an act. He takes the liberty to omit a suckling infant at her right breast, transforming her instead by sexualizing the whole set-up into a female Eros emphasizing her parallels with Venus. The symbols he employs are fair game for Freudians and Freudian dream interpretation ${ }^{33}$. Lucina emerges in Núñez' reception as powerful and most tangible in comparison to other representations of the goddess. We are confronted with a very Venerian Lucina, not Juno Lucina. The erotic aspects of the goddess of birth are dominating the figure. While masculinity might find erotic pleasure in the birthing process, labouring women most certainly do not. Núñez has a history of interest in female sexuality; his Tractado sobre el uso de las mugeres, published only a few years earlier in 1572. Unanswered remains the question of whether Francisco Núñez was the first to introduce the 'Venerian Lucina', and if so, whether his Lucina influenced later perception and reception, or, whether he had a role model.

\section{LUCINA AT THE ARCH OF SANTA MARÍA OF BURGOS}

Burgos prepared a special wedding gift for Philip III and Margaret of Austria, married procure in 1598, whose visit was scheduled in 160034. At the right side of the entrance of the Arco de Santa María of Burgos ${ }^{35}$ we encounter Lucina at the height of the cornice as a pagan and profane matter in a catholic environment, painted by Pedro Ruiz de Camargo in 1600 and rediscovered in 1877. Doubtlessly, she is Lucina, here Juno Lucina crowned with the crescent moon and Juno's peacock at her side. In her hands she holds a lance wrapped in a banner. «NUNC VENIT LUCINA, FUI QUAE PRONUBA VOBIS» «here comes now Lucina, your matron of honour», is written above the goddess. The banner that twins her right arm reads «PARTUS VEROSQUE SOLVO SIDEREA VIRTUTE CABALLI» bringing about a happy birth by the astral influence of the horse, referring to Pegasus the winged horse and Hipprocrene's fountain to enhance procreation ${ }^{36}$. Opposite, on the left, Lucina is accompanied and complemented by Venus, the goddess of love, annotated by «ET SAMIS ATQUE CYPRIS, DISCORDES TEMPORE LONGO, SUNT SIMUL, PULCHRA UT FACIANT VOS PROLE PARENTES» «and from Samos and from Cypress, for a long time in disagreement, here united to make you parents of a splendid descendant». The cause and background of Juno Lucina and Venus, entente cordial, remarkably rec-

\footnotetext{
31. Fabian, 1978, p. 80.

32. Milk and honey are traditionally found joint (in combination? together?), symbolizing abundance of nourishment, see Forstner, 1967 [1961], p. 475. The whole set is full of pictures of fertility.

33. Obviously, the trees and spikes represent phalli. The ocean is a symbol of the fountain of life and its reference to the amniotic fluids. See also Forstner, 1967 [1961], p. 73.

34. Martínez Burgos, 1949, p. 154.

35. For further details consult Martínez Burgos, 1949, pp. 153-160.

36. Hippocrene's fountain in Ovid, Fasti 5, $7 f$ and Metamorphoses 5, $255 f$.
} 
onciled after Paris, is the story of the recently wed, yet childless, royal couple, Philip III and Margaret of Austria, who's visit to Burgos was due, and due was an heir ${ }^{37}$. The artist Camargo was well aware of convenience marriage and conjugal duties and in the means of expression, he overlaps images of the goddess of birth and the matron of matrimony, Juno, who procrastinates or quickens birth as known through Ovid's Metamorphoses, when so operating as Juno Lucina, in Häussler's words:

Ob pluralisch oder singularisch: Hera selbst [...] verkörpert etwas vom Wesen der Geburtsgöttinnen: sie, die als Hera Eileithyia in Argos und Athen verehrt wird und bei den Dichtern mehr als einmal zu erkennen gibt, daß sie etwas von Geburten-Verzögerung bzw. -Beschleunigung versteht. Diesem Aspekt als Geburtsgöttin entspricht, wie jeder sieht, luno Lucina ${ }^{38}$.

The peacock on Lucina's side is Juno's attribute, but the banner names her Lucina, and Lucina only. The snake next to her is a symbol of a fertility ritual in ancient Rome ${ }^{39}$. Camargo pictures here a Lucina with Venus, side by side, entrance space in between, and undeniable aspects of Juno. Still, she is named Lucina, and not Juno Lucina. The artist employs this overlap of mythological figures as an allegory of erotic love in marriage with consequences, dropping a hint: lust might be aroused ${ }^{40}$. Soon after the king's and queen's visit to Burgos, Margaret gave birth to their first daughter, Ana María Mauricia, on 22 September in the year $1601^{41}$.

\section{LUCINA AND THE ALEGORÍA DEL NACIMIENTO DEL INFANTE DON FERNANDO}

We find a bright though distorted example of the goddess of birth in Micheli Tebano Parrasio's Alegoría del nacimiento del infante don Fernando of 1575, dedicated to the much desired and highly celebrated royal heir, Philip II and Anne of Austria's son, born on 4 December $1571^{42}$. The Venetian artist, Michelangelo and Titian's alumni, makes a virtue of necessity and sends with his best wishes his job application «deseando verse incluido en número de vuestros devotos servidores»

37. The Spanish society had been eagerly awaiting a royal birth. A triumphal arch in the Calle Mayor with oriental Indian and Antique allegories was erected and dedicated to Margaret for her arrival celebration on 24 October 1599, depicting Juno, Proteus, and Nero giving their best wishes to the newlyweds. See Rubio, 2010, p. 250 and Marín Tovar, 1999. José Salvador enumerates also Lucina second after Juno, see Salvador, 2001, p. 36

38. See Häussler, 1995, p. 78.

39. Virgins feeding snakes, a fertility ritual associated with the cult of Juno Sospita, see Fabian, 1978, p. 108.

40. Margaret of Austria spent 72 months of pregnancy during twelve years of marriage with Philip III, see Aichinger, 2014, p. 19.

41. See Rubio, 2010, p. 256.

42. See Rubio, 2010, p. 223. 
by virtue of painting ${ }^{43}$. The canvas of stately dimension ${ }^{44}$ exhibited in El Prado, is the painter's mythological-allegoric reading of the stars for the recently born successor of the Spanish throne. Its composition is based on religious birth representations and combines elements of classic mythology and Christian tradition ${ }^{45}$. The royal baby is surrounded by the seven sisters or seven virtues which in the orient is also referred to as the seven midwives. His mother, Queen Anne of Austria, is lying in bed behind them in the midst of seven putti or Cupidi. The scene is framed by a large, purpura red curtain held together by a crown trimmed with the Zodiacs, with Fama blowing the trumpet atop, proclaiming «CELEBRIS MUNDI VENERIS PARTUS»: «the world celebrates that Venus has given birth», calling all Spanish provinces to praise and honour their newborn king ${ }^{46}$. On the right above, Mars is sitting on an eagle on a cloud, and left above, enthroned on a cloud, Lucina ${ }^{47}$. The Alegoría is indeed an allegory, and a replete one. Seven virtues, seven Cupidi, seven arrows, two eagles, stars, roses, laurels, clouds, a scepter, a crown and a lot of that ilk. Lucina can hardly be understood without decoding the composition's complexity, which cannot be done here. However, amidst multiple layers of messages, one stands out: a great king is born ${ }^{48}$.

Lucina is depicted in a seated position ${ }^{49}$, her face slightly turned away from the scene below. She wears a blue greenish cloak, richly ornamented with golden stars, opened, displaying a robe of milky and light brown shades of colour girded right below her breasts, and pleated over a bulge. Her right hand supports the eagle's head, her left arm rests on her upper leg. The goddess seems calm and at peace, even indifferent to the birthing scene. She is positioned on the left side of the canvas representing the past, opposite to Mars on the right, predicting an even brighter future ${ }^{50}$ to come. A man might win the battle but does not have a future if it were

43. See the cover letter of the canvas sent by Micheli Tebano Parrasio to King Philip II, in Checa Cremades, 1994, p. 56. Unlike Titian, who was commissioned and instructed how to paint his Philip /I offering Fernando to Victory (1572-1575) by Philip II himself, picturing both favours of God, the victory of Lepanto and the birth of the male heir, Parrasio was not. See Serrera, 1990, p. 42.

44. Oil on canvas, $182 \times 223 \mathrm{~cm}$, exposed in Museo del Prado, Madrid. There is no information where it was hung, but was found listed in the inventory of Buen Retiro Palace 1701, see Webpage of Museo del Prado, 2017.

45. The birthing scene is obviously based on representations of the birth of the Virgin Mary. Queen Anne is depicted as Saint Anne, but simultaneously as Venus, see Kusche, 2007, p. 113.

46. See the cover letter of the canvas sent by Micheli Tebano Parrasio to King Philipp II, in Checa Cremades, 1994, p. 56.

47. Mars and Juno appear purposefully: Rosa María Cid López explains the relationship between Juno Lucina and Mars, both, military and birth, were exalted on 1 March. See Cid López, 2007.

48. The colours themselves indicate an important royal event. The curtain may be seen as the star, which breakthrough the «nubes de esterilidad», as mentioned by the artist in his letter, but often missed by its critics. Philip II took the birth of his son, the highly expected and celebrated heir after Don Carlos' death in 1568, as God's reward for his triumph at Lepanto, on 7 October 1571, two months before Fernando's birth. See Serrera, 1990, p. 42.

49. The sitting position refers to a state of peace and power, see Forstner, 1967 [1961], p. 26.

50. The brightest space of the scene is found on the right side below Mars, pointing to future victories. In Renaissance art theory artists already employ this technique on purpose, see Allscher et al., 1975, pp. 9-10. 
not for the woman ensuring continuity of his dynasty, thus presenting both male and female as equals.

Parrasio's 'Lucy in the sky' is a multiple personality. In this allegory, Lucina is goddess and virgin, whilst being Luna and Diana, crowned with the crescent moon, the universal symbol of female energy ${ }^{51}$. Lucina is not only the midwife assisting in birth but also powerfully sits on her throne. She is queen. She sits as a queen, a mighty ruler reigning over life and death and assumes the position of being the giver of life -a present she did not give of last ${ }^{52}$. She is a mother. She poses as a reigning mother, the matron Juno- matron of marriage and procreation. Lucina is pregnant, identified by her garment and folds over the bulge ${ }^{53}$. Queen Anne is set right in the centre of the canvas, nevertheless, Lucina is a Habsburgian here, maybe Anne herself. Her face looks as much Habsburgian as Philip II is portrayed as Mars. Each of them is accompanied by half of the double-headed Eagle: «he querido mostraros bajo qué planetas ha nacido Su Alteza sustentándose en las dos águilas, signo imperial que por una larga sucesión ha parado en la Casa de Austria» ${ }^{54}$, once again ambiguous by the fact that the two eagles are depicted on the canvas.

Interesting to note is that her blueish cloak decked with stars is unique and had never been part of Lucina's, Juno's or any queen's wardrobe ${ }^{55}$. However, the Lady to whom the victory of the sea battle of Lepanto was accredited to in legends, is wrapped in the greenish blue cloth: La Virgen de Guadalupe, Mexico ${ }^{56}$. Female grandeur always comes with a component of Lucina and what she represents: giving birth.

51. In ancient mythology, the goddess of the moon is the mistress of fertility and rhythms of life, influencing the tides, flora, fauna, and female menstruation. Lunar phases represent the threefold female circle of life. The crescent moon is the symbol of virgins, attribute of moon goddesses like Diana and Luna, see Göttner-Abendroth, 1991, pp. 45-46.

52. Philip II spent six hours beside his labouring wife Anne, traumatized by his fatal obstetrical experiences with his former wives, see Rubio, 2010, p. 223

53. Gregor Lechner describes «Maria Gravida», in Renaissance and Baroque Italian Art, being deciphered by her bulge, high belt, and the parallel pleads. The Madonna is wrapped in a wide cloak, which opens up to a dress, see Lechner, 1981, pp. 13, 15 and 34-35.

54. See the cover letter of the canvas sent by Michele Tebano Parrasio to King Philip II, in Checa Cremades, 1994, p. 56. Mars and Lucina represent king and queen, as symbols of sun and moon. Further information about lunatic metaphors and Spanish queens may be obtained from Mínguez, 1993.

55. The blue colour in Marian representations refers to her state of everlasting virginity, blue in general stands for purity and as symbol for the firmament. See Forstner 1967 [1961], p. 125. In Cartari, Le imagini colla spozione degli dei degli antichi, p. 148, «Two images of Jupiter», Jupiter is dressed in a white mantle bespangled with stars.

56. The cult of the Virgin Mary affirmed by the miracle of Guadalupe in 1531 led to mass conversions in 'las Americas', which had a major impact on the Spanish conquest. See Remensnyder 2014, pp. 326-328 and 301; King Philip II received one of the first copies of the miracle of Guadalupe, which was bestowed to Admiral Gian Andrea Doria, who fought the battle of Lepanto. See Johnston, 2011, p. 70, Legends formed attributing the victory to the image of Guadalupe. See also Bicheno, 2003 and Mínguez, 2011. 


\section{NOT ALL THAT GLITTERS IS GOLD. LUCINA IN THE GOLDEN AGE}

Mankind tends to pose questions and have them answered and in finding fault likes to shift the blame to anybody and anything (except themselves). Do gods serve as patsies? Does it fit into the narrative to hold the not-all-powerful deities accountable for misfortune and losses, when the perfect Mother of God cannot be blamed? Isabel Colón Calderón points to the fact that parturient catholic women of the Golden Age called out to the intercessor Virgin Mary, lyric invocations to Lucina «fueron un mitológico encubrimiento de la peligrosa realidad del parto» ${ }^{57}$. As Colón Calderón elaborated in her article «Hacia una visión lírica de la realidad, la invocación a Lucina», Lucina is in most Spanish Golden Age poetry blamed for the failure and death in labour. Sofie Kluge speaks of the ambiguous allegories of a «fertile ground for therapeutically venting the tragic» ${ }^{58}$ and says:

In Baroque mythological literature, myth is a medium for presenting controversial issues in a dialectical manner; for making ambiguous statements; and for creating irreducibly complex syntheses of apparently irreconcilable perspectives ${ }^{59}$.

The catholic Spanish society of the 16th century prayed to their intercessors, and above all, to Mary, yet Lucina maintains a certain allegoric presence as shown above. However, Jean Seznec expresses it as «a stream into which flow all waters of the past, mingling the most diverse forms and ideas, fusing Christian allegory with the ancient symbols of the barbarian religions» ${ }^{60}$, and is proven right by this poem:

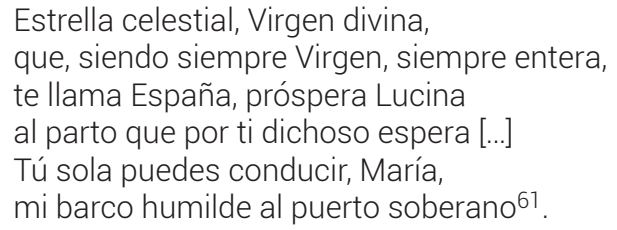

Lope de Vega uses such a lyric artifice in his La Almudena, dedicated to the expecting queen Isabel, addressing the Virgin Mary by referring to Lucina. They might be exchangeable, yet not mutually. Birth and delivery last a few hours, likewise, Lucina is a 'nine-day-wonder'. Mary is exalted high, being multi-purposeful, if not all-purposeful. Lucina on the other hand 'caters' to the few hours of birth, hence, she is of a certain allegoric content and kept artificially alive in the arts. As a newborn is not independent, Lucina does not appear independently. In the analyzed examples she is a vessel, useful to be filled with any message the artist wants to send. Francisco Núñez has an erotic muse of natal matters. In Burgos Lucina and Venus are being used as proxies for brazen demands. Micheli Parrasio fills the

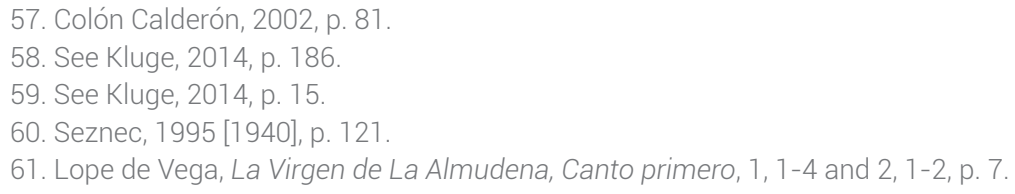


vessel to the brim with a 'seven-headed Lucina' - a conjunction of several female topoi. Lope de Vega and others uncover a failing goddess incapable of her task. In literature, Lucina is as if 'cast down from Mount Olympus', because she is a capricious goddess who comes late or never to assist in labour. Her merely negative appearance in literature contrasts her rich allegoric appearances in royal contexts. Renaissance flares up the allegoric power of the ancient goddess Lucina, yet Stella Maris shines brighter.

It is worth considering broadening the scope of this study since the subject has not been exhausted. Future exploration of other wide-ranged sources of the goddess of birth such as for example in early modern Iberian festival culture ${ }^{62}$, as well as in Latin contemporary treatises ${ }^{63}$ promises further results.

\section{BIBLIOGRAPHY}

Allscher, Ludger et al. (eds.), Lexikon der Kunst in vier Bänden, Band 3 Li-P, Leipzig, Seemann, 1975.

Aichinger, Wolfram, «El parto violento en Calderón y el dramatismo del parto en la España del Siglo de Oro», in La violencia en el teatro de Calderón, ed. Manfred Tietz and Gero Arnscheidt, Vigo, Academia del Hispanismo, 2014.

Backe-Dahmen, Annika, Die Welt der Kinder in der Antike, Mainz am Rhein, Philipp von Zabern, 2008.

Bicheno, Hugh, Crescent and Cross. The Battle of Lepanto, 1571, London, Cassel, 2003.

Boccaccio, Giovanni di, Genealogia deorum gentilium [1350-1367], ed. Vincenzo Romano, Bari, Laterza, 1951.

Campus Hernán, María del Pilar and Moreno Martín, José María, Catálogo de documentos de Bernardino de Avellaneda en el archivo del Conde de Orgaz (15701636), Madrid, Museo Naval de Madrid, 2005.

Carranza, Alonso de, Disputatio de Vera Humani Partus Naturalis et Legitimi Designatione, Madrid, Francisco Martínez, 1628.

Cartari, Vincenzo, Le imagini colla spozione degli dei degli antichi, Venice, 1556.

Checa Cremades, Fernando, Tiziano y la monarquía hispánica. Usos y funciones de la pintura veneciana en España (siglos XVI-XVII), Madrid, Nerea, 1994.

Cid López, Rosa María, «Imágenes y prácticas en la sumisión femenina en la antigua Roma. El culto de "Juno Lucina" y la fiesta de "Matronalia"», Studia Historica: Historia Antigua, 25, 2007, pp. 357-372.

62. The literary genre «reaciones de fiestas barrocas» on the subject of birth, fertility and related topics is a rich fountain of interpretation of Spanish baroque culture.

63. Alonso de Carranza presents Lucina the goddess of birth in the introduction of his moral treatise on childbirth, see Carranza, Disputatio de Vera Humani Partus Naturalis et Legitimi Designatione. 
Colón Calderón, Isabel, «Hacia una visión lírica de la realidad, la invocación a Lucina», in Estudios sobre tradición clásica y mitología en el Siglo de Oro, ed. Isabel Colón Calderón and Jesús Ponce Cárdenas, Madrid, Ediciones Clásicas, 2002, pp. 73-82.

Dierichs, Angelika, Von der Götter Geburt und der Frauen Niederkunft, Main am Rhein, Von Zabern, 2002 (Kulturgeschichte der antiken Welt, Band 82).

Fabian, Klaus-Dietrich, Aspekte einer Entwicklungsgeschichte der römisch-lateinischen Göttin Iuno, Inaugural-Dissertation, Berlin, 1978.

Forstner, Dorothea, Die Welt der Symbole, Innsbruck/Wien/München, Tyrolia, 1967 [1961].

García Barranco, Margarita, Antropología histórica de una élite de poder, las reinas de España, Dissertation, Granada, University of Granada, 2007.

Gottschalk, Herbert, Lexikon der Mythologie, München, Heyne, 1993.

Göttner-Abendroth, Heide, Die tanzende Göttin: Prinzipien einer matriarchalen Ästhetik, München, Frauenoffensive, 1991 [1982].

Häussler, Reinhard, Hera und Juno, Wandlungen und Beharrungen einer Göttin, Stuttgart, Steiner, 1995.

Herrera, Fernando de, Obras de Garcilaso de la Vega con anotaciones, in Garcilaso de la Vega y sus comentaristas, ed. Antonio Gallego Morell, Madrid, Gredos, 1972, pp. 307-594.

Homerus, The Iliad of Homer, Book XI, ed. Forster, Edward, Letchworth, Bradda Books, 1981.

Johnston, Francis, The Wonder of Guadalupe. The Origin and Cult of the Miraculous Image of the Blessed Virgin in Mexico, Charlotte, Tan Books, 2011.

Kluge, Sofie, Diglossia: The Early Modern Reinvention of Mythological Discourse,

Kassel, Reichenberger, 2014.

Kusche, María, Juan Pantoja de la Cruz y sus seguidores, Madrid, Fundación Arte Hispánico, 2007.

Lechner, Gregor, Maria Gravida, Zum Schwangerschaftsmotiv in der bildenden Kunst, München/Zürich, Schnell \& Steiner, 1981.

Marín Tovar, Cristóbal, «La jubilosa entrada de Margarita de Austria en Madrid», Anales de Historia del Arte, 9, 1999, pp. 147-157.

Martínez Berbel, Juan Antonio, El mundo mitológico de Lope de Vega. Siete comedias mitológicas de inspiración ovidiana, Madrid, Fundación Universitaria Española, 2003. 
Martínez Burgos, Matías, «Torre y arco de Santa María», Boletín de la Comisión provincial de Monumentos y de la Institución Fernán González de la ciudad de Burgos, 28, 108, 1949, pp. 153-160.

Martínez Hernández, Santiago, El marqués de Velada y la corte en los reinados de Felipe II y Felipe III. Nobleza cortesana y cultura política en la España del Siglo de Oro, Salamanca, Junta de Castilla y León, 2004.

Mínguez, Víctor, «La metáfora lunar: la imagen de la reina en la emblemática española», Millars. Espai i historia, 16, 1993, pp. 29-46.

Mínguez, Víctor, «lconografía de Lepanto. Arte, propaganda y representación simbólica de una monarquía universal y católica», Obradoiro de historia moderna, 20, 2011, pp. 251-280.

Núñez, Francisco de Coria (Oria), Tractado del uso de las mugeres, y como sea dañoso, y como provechoso, y que cosas se ayan de hazer para la tentacion de la carne, y del sueño y vaños, Madrid, Pierres Cusin, 1572.

Núñez, Francisco de Coria (Oria), Libro intitulado del parto humano, en el cual se contienen remedios muy vtiles y vsuales para en parto difficultoso de las mugeres, con otros muchos secretos a ello pertenescientes, Alcalá, en casa de Juan Gracián, 1580.

Petersmann, Hubert, «Lucina nixusque pares. Die Geburtsgottheiten in Ovids Met. IX 294 Variationen eines mythologischen Motivs», Rheinisches Museum für Philologie, 133.2, 1990, pp. 157-175.

Pérez de Moya, Juan, Philosophia secreta donde debaxo de historias fabulosas, se contiene mucha doctrina provechosa a todos estudios, con el origen de los idolos, o dioses de la gentilidad, Madrid, en casa de Francisco Sánchez impresor, 1585.

Pérez de Moya, Juan, Comparaciones o símiles para los vicios y virtudes. Philosophía secreta [1585], ed. Consolación Baranda, Madrid, José Antonio de Castro, 1996.

Ovid, Metamorphosen, ed. Niklas Holzberg, Berlin/Boston, De Gruyter, 2017.

Ovidius Naso, Publius, Metamorphoses, translated by Humphries, Rolfe, Book Nine, The Story of Hercules' Birth, Bloomington, Indiana University Press, 1983.

Ovidius Naso, Publius, Fasti 2, ed. Matthew Robinson, Oxford, Oxford University Press, 2011.

Salvador, José María, Efímeras efemérides. Fiestas cívicas y arte efímero en la Venezuela de los siglos XVII-XIX, Caracas, Universidad Católica San Andrés Bello, 2001.

Serrera, Juan Miguel, «Alonso Sánchez Coello y la mecánica de retrato del Corte» in Alonso Sánchez Coello y la mecánica de retrato del Corte de Felipe II, Madrid, Museo del Prado, El Viso, 1990. 
Seznec, Jean, The Survival of the Pagan Gods, The Mythological Tradition and its Place in Renaissance Humanism and Art, New York, Princeton University Press, 1995 [1940].

Vega Carpio, Lope Félix de, La Virgen de la Almudena (Poema histórico), ed. José Fradejas Lebrero, Madrid, Instituto de Estudios Madrileños, 1993.

Radke, Gerhard, Die Götter Altitaliens, Münster, Aschendorff, 1965.

Remensnyder, Amy, La Conquistadora. The Virgin Mary at War and Peace in the Old and New World, New York, Oxford University Press, 2014.

Rubio, María José, Reinas de España, siglos XV-XVII. De Isabel la Católica a Mariana de Neoburgo, Madrid, La Esfera de los Libros, 2010.

\section{PAINTINGS}

Camassei, Andrea, Fiestas Lupercales, 1635, oil on canvas, 238 × 366 cm, Museo del Prado, Madrid.

Parrasio, Micheli Tebano, Alegoría del nacimiento del infante don Fernando, 1575, oil on canvas, $182 \times 223 \mathrm{~cm}$, Museo del Prado, Madrid.

Titian, Vecellio, Philip II offering the Infante don Ferdinand to Victory, 1573-1575, oil on canvas, 335 × $274 \mathrm{~cm}$, Museo del Prado, Madrid.

\section{INTERNET}

Museo del Prado: <https://www.museodelprado.es/coleccion/obra-de-arte/alegoria-del-nacimiento-del-infante-don-fernando/c719da5a-f02e-428d-856f07d10b0f3e80> [16-12-2017]. 